\title{
Jack Widness: the importance of connections
}

\author{
Steven J. McElroy ${ }^{1}$
}

\section{JOHN (JACK) WIDNESS, MD}

$I^{t}$ is with great pleasure that we honor the distinguished career of our colleague and friend, John (Jack) A. Widness, MD, Professor of Pediatrics, Division of Neonatology, Stead Family Department of Pediatrics, University of Iowa, at his retirement after nearly 40 years of teaching, outstanding clinical practice, and paradigm-shifting research. Jack is a member of a small group of researchers that received continuous funding support from the NIH for nearly 40 years, beginning with his postdoctoral training in 1978. Jack's time at Iowa began in 1988 (Figure 1a) when Frank Morriss, $\mathrm{MD}$, then chair of Pediatrics, and Ed Bell, MD, the new division director of Neonatology, recruited him from Brown University. Ed and Jack were trained together at Brown and have been friends for more than four decades (Figure 1b), which provides some insight into how deeply Jack invests in his friendships.

Throughout his career, Jack's research focused on advancing the knowledge of fetal and neonatal hematology with a major emphasis on anemia prevention. His interests were broad, his methodology thoughtful, and his persistence unflagging. His work on erythropoiesis, the physiology and pharmacology of erythropoietin (EPO), perinatal iron metabolism, and transfusion medicine set new standards and provided important groundwork on which others have continued to build. One of the hallmarks of his career has been his unique gift for identifying, creating, and leading successful collaborations-and perhaps even rarer-he enjoyed the process. Jack would tell you that his numerous national and international collaborations, which have led to several seminal discoveries, were part of what has made his career "fun." Nonetheless, the primary goal of his collaborative efforts was always that they would ultimately benefit the patient. This can be clearly seen in the additional essays written on Jack's behalf and are contained in a Festschrift that can be accessed at https://medicine.uiowa.edu/pediatrics/jackwidness-importance-connections.

Jack has always been driven to succeed. At Amherst College, he graduated cum laude as well as being named an NCAA All-American lacrosse player. He then pursued a medical career at Duke University Medical School, following which he completed an internal medicine internship at the University of Pittsburgh and a pediatric residency at Case Western Reserve University. Jack's research career began in earnest during his fellowship and continued for the next decade as a faculty member at Brown University under the guidance of Robert Schwartz, MD, and Bill Oh, MD. Together with Bob's brother, Herbert Schwartz, MD, Jack and his research colleagues (including members from Finland, Canada, and Austria) were part of a program project grant that focused on the clinical-translational aspects of glycohemoglobin in diabetic pregnancies. Utilizing the first assay for glycosylated hemoglobin, Jack's manuscript (the first of over 200) demonstrated that maternal $\mathrm{HbA}_{1 \mathrm{c}}$ levels were indicators of maternal diabetic glucose control (1) and were associated with fetal growth and fetal hypoxia (2).

In Iowa, Jack continued to pursue his interest in erythropoiesis and specifically EPO administration in anemic infants. This work was propelled by a highly productive collaboration with Peter Veng-Pedersen, PhD, which continued for 25 years and resulted in the publication of more than 50 peer-reviewed manuscripts. The findings included demonstrating that EPO pharmacokinetic behavior in both infants and adults was nonlinear (3) and the development of new modeling that estimated a newborn infant's endogenous capacity to respond to EPO for sustained stimulated erythropoiesis (4). Blood loss from laboratory phlebotomy and its role as an important contributor to anemia, and the need for red blood cell (RBC) transfusions in critically ill neonates was another long-standing interest for Jack. Early on, he perceptively called attention to the fact that we were withdrawing more blood from babies for lab tests than was needed (5). His studies included a randomized trial that utilized an ex vivo in-line monitor and benchtop and pointof-care analyzers that required smaller blood volumes than standard phlebotomy (6).

With the goals of identifying an optimal RBC transfusion product for infants and understanding the mechanisms of RBC survival, Jack and Don Mock, MD, PhD, created a method for labeling RBCs at multiple biotin densities for use in RBC kinetic survival studies that can be measured using flow cytometry (7), and a method for detecting antibodies

\footnotetext{
'Division of Neonatology, Department of Microbiology and Immunology, Stead Family Department of Pediatrics, Carver College of Medicine, University of lowa, lowa City, lowa. Correspondence: Steven J. McElroy (steven-mcelroy@uiowa.edu)

Received 26 September 2017; accepted 22 September 2017; advance online publication 10 January 2018. doi:10.1038/pr.2017.317
} 


\section{Commentary | McElroy}
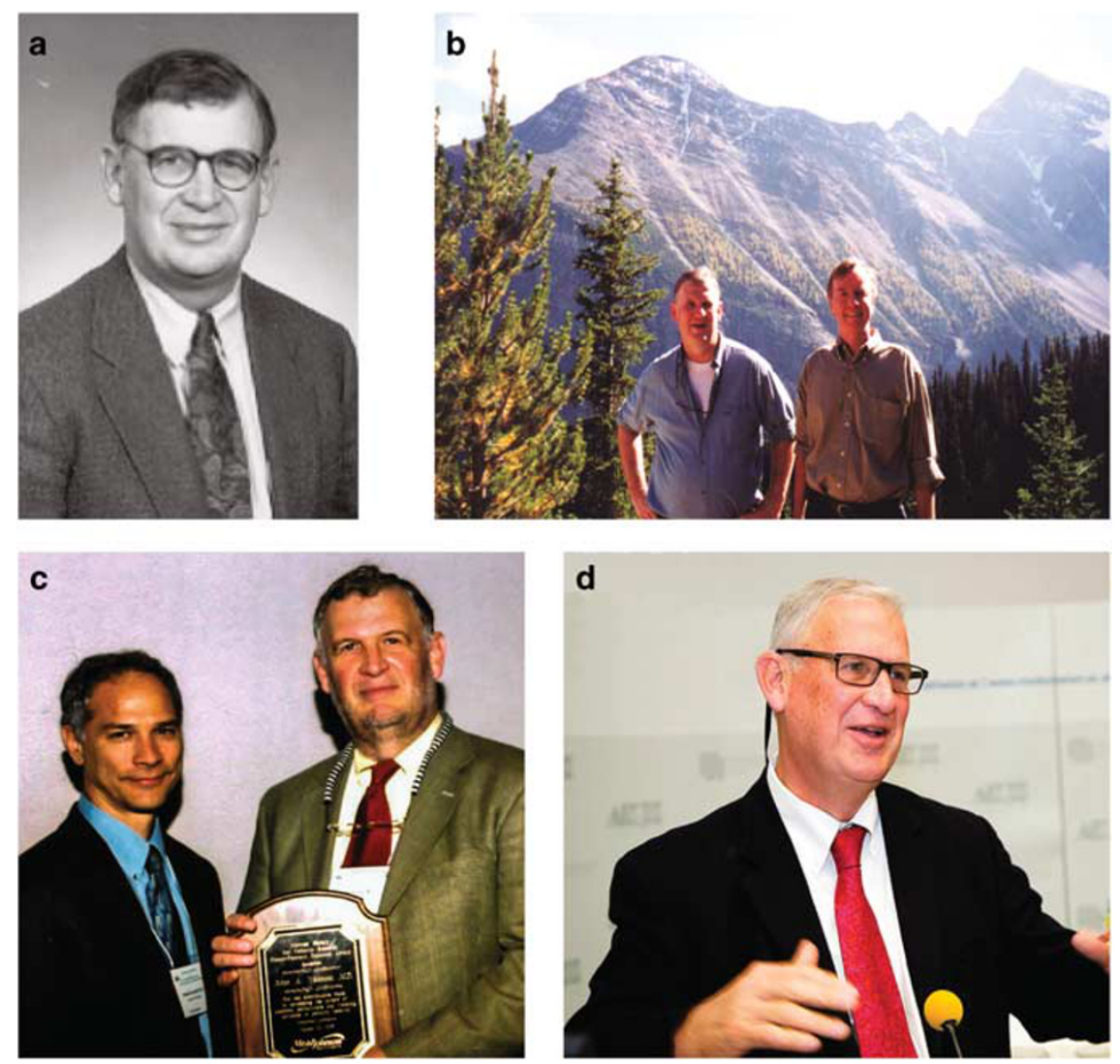

Figure 1. Faculty photo of John "Jack" Widness, 1988, University of lowa (a). Ed Bell and Jack Widness at the Perinatal Research Society Meeting in 2002 (b). Jack Widness receiving the 2005 Midwest Society for Pediatric Research Founder's Award from Michael Georgieff (c). Jack Widness teaching at the Abschiedsymposium for Arnold Pollak, 2014 (d).

to biotinylated red cells that are occasionally observed in adults (8).

Along with Ron Strauss, MD, Don Mock, Peter VengPedersen, Ed Bell, and statistician, Leon Burmeister, Jack was a founding member of the "Iowa Neonatal Anemia Program Project Grant" in 1992. He assumed overall PPG leadership as principal investigator from Ron Strauss in 2006 and, as the program director, he secured renewal through two 5-year cycles and included investigators and consultants from two European and 12 US universities. One of many projects funded from the Iowa Anemia PPG included a randomized controlled trial of liberal vs. restrictive guidelines for RBC transfusions in preterm infants (9). The findings (10) in part led to the NIH-funded Transfusion of Prematures trial, which hopes to improve our understanding and practice of transfusions in preterm infants.

Fruitful collaborations with David Stevenson, MD, Stanford University, and Sandra Juul, MD, University of Washington, were additional highlights of Jack's career. He and David began their professional friendship with the Schwartz brothers at their individual institutions. Over the years, Jack and David continued discussions concerning their interest in infants of diabetic mothers, alloimmunized pregnancies (11), hemolysis (12), and anemia. This ultimately resulted in six joint manuscripts-and decades of continuing friendship. In addition, at Sandra's request, Jack became the medical monitor for the PENUT (Preterm EPO Neuroprotection) study during patient enrollment, 2013-2016.

Jack's propensity for collaborations was again illustrated when he was asked to assume the directorship of the Iowa Neonatal Fellowship Program, where he took it upon himself to create a series of didactic, interactive seminars for neonatal fellows that was so successful that it was soon offered to all pediatric fellows at Iowa. This innovative curriculum was integrated at Iowa before it became required by the ACGME nationwide and resulted in similar programs being offered at Midwest Society for Pediatric Research meetings in collaboration with other fellowship programs. These accomplishments contributed to Jack being awarded the 2005 MWSPR Founders' Award (Figure 1c). In addition, Jack's successful endeavors led to memberships in the Society for Pediatric Research, the American Pediatric Society, the Perinatal Research Society, and the International Perinatal Collegium. As a member of the Thrasher Research Fund's Scientific Advisory Committee for 8 years, Jack was the original proposer for the concept of awarding research grants to postdoctoral and early-faculty researchers. Currently, up to 30 Thrasher Early Career Awards are bestowed annually. 


\section{Commentary | Commentary}

In 2017, Jack's love of the outdoors is taking him and his wife Michaelanne ("Mike") back to Lake Raponda in southern Vermont where they have spent many happy summers. We will miss his input, his collaborative leadership, and our daily encounters, but if the past is any indication, our friendships will continue. We deeply thank Dr. Widness for his contributions to the field of neonatology, for his commitment to the many trainees and junior faculty he has mentored, to the peer scientists he has inspired, and to the countless infants whose lives he has impacted through his esteemed career (Figure 1d).

\section{ACKNOWLEDGMENTS}

I gratefully thank Corey Nason Reese for helping to review and edit the manuscript. I also thank the following for contributing to Jack's complete Festschrift, which can be found online at: https://medicine.uiowa.edu/ pediatrics/jack-widness-importance-connections

Judy Aschner, MD, Edward F. Bell, MD, Michael K. Georgieff, MD, Sandra E. Juul, MD, PhD, Pamela J. Kling, MD, Frank H. Morriss, Jr., MD, MPH, William Oh, MD, Jeffrey L. Segar, MD, Martha Sola-Visner, MD, David K. Stevenson, MD, and Ronald G. Strauss, MD.

\section{STATEMENT OF FINANCIAL SUPPORT}

This study was funded by the Stead Family Department of Pediatrics, University of lowa.

Disclosure: The author declares no conflict of interest.

\section{REFERENCES}

1. Widness JA, Schwartz HC, Thompson D, et al. Glycohemoglobin (HbAIc): a predictor of birth weight in infants of diabetic mothers. J Pediatr 1978;92: $8-12$.
2. Widness JA, Schwartz HC, Thompson D, Kahn CB, Oh W, Schwartz R. Haemoglobin Aic (glycohaemoglobin) in diabetic pregnancy: an indicator of glucose control and fetal size. Br J Obstet Gynaecol 1978;85:812-7.

3. Widness JA, Veng-Pedersen P, Peters C, Pereira LM, Schmidt RL, Lowe LS. Erythropoietin pharmacokinetics in premature infants: developmental, nonlinearity, and treatment effects. J Appl Physiol 1996;80:140-8.

4. Freise KJ, Widness JA, Veng-Pedersen P. Erythropoietic response to endogenous erythropoietin in premature very low birth weight infants. J Pharmacol Exp Ther 2010;332:229-37.

5. Lin JC, Strauss RG, Kulhavy JC, et al. Phlebotomy overdraw in the neonatal intensive care nursery. Pediatrics 2000;106:E19.

6. Widness JA, Madan A, Grindeanu LA, Zimmerman MB, Wong DK, Stevenson DK. Reduction in red blood cell transfusions among preterm infants: results of a randomized trial with an in-line blood gas and chemistry monitor. Pediatrics 2005;115:1299-306.

7. Mock DM, Lankford GL, Widness JA, Burmeister LF, Kahn D, Strauss RG. RBCs labeled at two biotin densities permit simultaneous and repeated measurements of circulating RBC volume. Transfusion 2004;44: 431-7.

8. Schmidt RL, Mock DM, Franco RS, et al. Antibodies to biotinylated red blood cells in adults and infants: improved detection, partial characterization, and dependence on red blood cell-biotin dose. Transfusion 2017;57:1488-96.

9. Bell EF, Strauss RG, Widness JA, et al. Randomized trial of liberal versus restrictive guidelines for red blood cell transfusion in preterm infants. Pediatrics 2005;115:1685-91.

10. Nopoulos PC, Conrad AL, Bell EF, et al. Long-term outcome of brain structure in premature infants: effects of liberal vs restricted red blood cell transfusions. Arch Pediatr Adolesc Med 2011;165:443-50.

11. Widness JA, Lowe LS, Stevenson DK, et al. Direct relationship of fetal carboxyhemoglobin with hemolysis in alloimmunized pregnancies. Pediatr Res 1994;35:713-9.

12. Hayde M, Widness JA, Pollak A, Kohlhauser-Vollmuth C, Vreman HJ, Stevenson DK. Rhesus isoimmunization: increased hemolysis during early infancy. Pediatr Res 1997;41:716-21. 